Article

\title{
The Use of Concentrates Rich in Orange By-Products in Goat Feed and Its Effects on Physico-Chemical, Textural, Fatty Acids, Volatile Compounds and Sensory Characteristics of the Meat of Suckling Kids
}

\author{
José Luis Guzmán ${ }^{1}\left(0\right.$, Manuel Delgado-Pertínez ${ }^{2}{ }^{\circledR}$, María José Beriáin ${ }^{3}{ }^{\circledR}$, Rafael Pino ${ }^{4}$, \\ Luis Ángel Zarazaga ${ }^{1}$ and Alberto Horcada ${ }^{2, *}$ \\ 1 Departamento de Ciencias Agroforestales, ETSI, Universidad de Huelva, “Campus de Excelencia \\ Internacional Agroalimentario, ceiA3", Campus de la Rábida, 21819 Palos de la Frontera, Huelva, Spain; \\ guzman@uhu.es (J.L.G.); zarazaga@uhu.es (L.Á.Z.) \\ 2 Departamento de Ciencias Agroforestales, ETSIA, Universidad de Sevilla, 41013 Sevilla, Spain; \\ pertinez@us.es \\ 3 Research Institute for Innovation \& Sustainable Development in Food Chain (ISFOOD), Universidad Pública \\ de Navarra, 31006 Pamplona, Spain; mjberiain@unavarra.es \\ 4 Departamento de Estadística e Investigación Operativa, Facultad de Matemáticas, Universidad de Sevilla, \\ 41012 Sevilla, Spain; rafaelp@us.es \\ * Correspondence: albertohi@us.es; Tel.: +34-954486448
}

Received: 9 March 2020; Accepted: 20 April 2020; Published: 28 April 2020

Simple Summary: Spain is a major global producer of both goats and citrus fruits on the world. Using by-products of the orange industry for feeding ruminants has environmental advantages. In this work, we analysed how replacing cereal concentrates with dehydrated orange pulp (DOP) in the diet of mother goats affects the meat quality of suckling kids. We evaluated the following characteristics of the meat of suckling kids of the dairy Payoya breed: chemical composition; texture; water holding capacity; colour; saturated, monounsaturated, and polyunsaturated fatty acids (SFA, MUFA, and PUFA, respectively); volatile compounds; and sensorial appraisal. The inclusion of DOP in goat feed did not affect the proximal composition, texture, colour, or juiciness of the kids' meat. However, the inclusion of DOP improved the indices of the nutritional value of the meat for human health (thrombogenicity index, PUFA/SFA ratio, and n-6/n-3 ratio). The inclusion of DOP in goat feed reduced MUFA content in the kids' meat. An increase in aromatic compounds, including ethyl furan, dimethyl disulphide, and heptane, was observed in the grilled meat of kids from goats that were fed DOP. The use of DOP in goat feed improved consumers' sensory appreciation of the suckling kids' meat.

Abstract: We analysed how replacing cereal concentrates with dehydrated orange pulp (DOP) in the diet of mother goats affects the meat quality of suckling kids. Three experimental diets for mother goats were designed. The DOP-0 diet contained commercial concentrates and alfalfa hay. In the DOP- 40 and DOP- 80 diets, $40 \%$ and $80 \%$ (respectively) of the cereal in the concentrate was replaced with pellets of DOP (the alfalfa hay component was unchanged). We evaluated the chemical composition, texture, water holding capacity, colour, fatty acids (FAs) profile, volatile compounds, and sensorial appraisal of the meat from 30 male suckling kids (cold carcass weight $4.74 \mathrm{~kg}, 4.82 \mathrm{~kg}$, and $4.65 \mathrm{~kg}$ for DOP-0, DOP-40, and DOP-80, respectively) of the Payoya breed $(\mathrm{n}=10$ for each diet). Meat from kids in the DOP-40 and DOP- 80 groups exhibited characteristics favourable for human health, including the meat's thrombogenicity index, PUFA/SFA ratio ( 0.60 index), and n-6 PUFA/n-3 PUFA ratio (approximately 7.50). The meat also exhibited reduced MUFA content (around $460 \mathrm{mg} / 100 \mathrm{~g}$ fresh meat). An increase in ethyl furan, dimethyl disulphide and heptane was 
observed in grilled meat from goats that were fed using DOP. The inclusion of DOP in goat feed improved consumers' sensory appreciation of the kid's meat.

Keywords: by-products; feeding sources; goats; orange pulp

\section{Introduction}

Spain is a major producer of both goats and dehydrated orange pulp (DOP). In 2017, Spain had the second-highest number of goats of any European country $\left(3.06 \times 10^{6}\right)$ and was the top producer of oranges in Europe $\left(3.35 \times 10^{6} \mathrm{t}\right)$ [1]. Goats are mainly raised for milk production for the cheese industry. However, goat farms also produce suckling kid goats, which are exclusively fed with mother's milk for one month until they are slaughtered with a live weight of 8-10 kg [2].

Approximately $75 \%$ of Spanish orange production is devoted to fresh consumption and the remainder is for industrial production of orange juice [3]. The orange juice industry produces organic waste that can be used for other purposes. More specifically, DOP is a by-product of fruit juice extraction and consists of the dried residue of orange peels, pulp, and seeds. The processing of orange juice can generate waste of up to $15 \% w / w$ with respect to input, so it is important to consider options for its reuse. One possibility is to include orange waste in animal feed in the form of dried pellets, especially as a high-energy feed for ruminants to support growth and lactation. Technological advances have been made in the manufacture of animal feed, and the manufacture of dried feed pellets using orange by-products is now common. This represents a qualitative advantage to using orange by-products in animal feed.

Previous studies have focused on the effects of citrus pulp on animal growth and nutrition [4], but little is known about the effects of orange pulp on meat quality. Several studies have investigated the use of DOP by-product feed for sheep and have assessed the feed's effect on the meat quality of lamb. Some of these studies [5] have demonstrated the advantages of replacing the cereals in concentrate-based sheep diets with dried DOP as a feasible strategy to naturally improve the meat's oxidative stability. This is possible because using DOP by-products in sheep diets generates more moderate fermentations that can alter the profile of volatile fatty acids, basic milk compounds, and precursors of fatty acids (FAs) in meat [6]. Caparra et al. [7] found that the inclusion of dried DOP in lamb diets produced meat with lower redness values compared with the meat from lambs raised on a grain-based diet.

In Spain, the Payoya breed is being re-oriented to an intensive milk production system. Therefore, goat's farmers require feeding alternatives to achieve greater milk yields. The use of local alternative feeds can offer economic advantages by reducing feeding costs and mitigating the adverse socio-environmental impacts that would otherwise arise from the disposal of agri-industrial by-products [8]. The objective of the present study is to assess the effect of replacing cereal concentrates in goat feed with two levels of dehydrated orange pulp on the meat quality of the goats' suckling kids.

\section{Materials and Methods}

\subsection{Animal Management and Dietary Treatments}

Thirty male Payoya suckling kid goats were used for the feeding trial on an experimental farm at Huelva University (Spain). Previously, 44 first-kidding goats were distributed into three experimental groups according to isoenergetic and isoproteic dietary treatments. The groups were balanced according to their live weight and body condition. The three diets of feed were as follows: DOP-0 ( $n=14)$ composed of commercial concentrates with alfalfa hay, DOP-40 $(n=16)$ composed of commercial concentrates and alfalfa hay with $40 \%$ of concentrate cereals replaced with DOP pellets, and DOP-80 ( $n=14)$ composed of commercial concentrates and alfalfa hay with $80 \%$ of concentrate cereals replaced with DOP pellets (Table 1). The mean live weights of the goats in each group were 
$37.0 \pm 1.26,38.0 \pm 1.33$ and $37.5 \pm 2.12 \mathrm{~kg}$ for the DOP-0, DOP-40, and DOP-80 groups, respectively. The groups' mean body condition values were $2.76 \pm 0.09,2.51 \pm 0.06$, and $2.55 \pm 0.08$ for the DOP-0, DOP-40 and DOP-80 groups, respectively. From the beginning of the third month of gestation, DOP was gradually introduced into the diet of the animals in the DOP-40 and DOP-80 groups, and before application the experimental diets, visual observation of feed intake indicated that goats consumed all DOP pellets offered. Thus, changes in feed composition did not influence the palatability of the diets. During the last month of pregnancy, each group of animals received its corresponding experimental prepartum diet (on average, goats were fed $0.45 \mathrm{~kg} / \mathrm{d}$ of alfalfa hay and $0.7 \mathrm{~kg} / \mathrm{d}$ of concentrate per animal), with a 60:40 concentrate-to-forage ratio. After parturition and during the suckling period, the animals were given the experimental diets adapted to early lactation (Table 1; on average, goats were fed $0.4 \mathrm{~kg} / \mathrm{d}$ of alfalfa hay and $1.67 \mathrm{~kg} / \mathrm{d}$ of concentrate per animal), which consisted of a concentrate-to-forage ratio of 80:20. Although the individual intake was not measured, the average intake per animal obtained indirectly through the consumption of the group shows similar values in the different dietary treatments (DM was $1.85,1.82$ and $1.80 \mathrm{~kg} / \mathrm{d}$, protein digestible in the intestine was $0.19,0.20$ and $0.20 \mathrm{~kg} / \mathrm{d}$, and gross energy was $8.42,8.10$ and $8.00 \mathrm{Mcal} / \mathrm{d}$ in the DOP-0, DOP-40 and DOP-80 groups, respectively).

Table 1. Ingredients, chemical composition, nutritive value, and proximate fatty acid (FA) composition of the experimental diets ${ }^{1}$ used to feed the Payoya goats.

\begin{tabular}{|c|c|c|c|}
\hline Ingredients (\% Dry Matter Basis) & DOP-0 & DOP-40 & DOP-80 \\
\hline Alfalfa hay & 17.44 & 17.53 & 17.64 \\
\hline \multicolumn{4}{|l|}{ Concentrate } \\
\hline Dehydrated orange pulp (pellets) & 0.00 & 19.96 & 39.87 \\
\hline Grain (oats) & 22.10 & 13.23 & 4.38 \\
\hline Grain (barley) & 8.53 & 5.11 & 1.70 \\
\hline Grain (corn) & 19.34 & 11.61 & 3.89 \\
\hline Soy flour $44 \%$ & 7.31 & 10.23 & 12.97 \\
\hline Sunflower pellets $28 \%$ & 12.84 & 12.50 & 13.78 \\
\hline Grain (peas) & 10.32 & 8.12 & 4.05 \\
\hline Salt & 0.41 & 0.41 & 0.41 \\
\hline Stabilised butter & 0.41 & 0.00 & 0.00 \\
\hline Vitamins and minerals ${ }^{2}$ & 1.31 & 1.31 & 1.32 \\
\hline \multicolumn{4}{|l|}{ Chemical Composition (\% Dry Matter Basis) } \\
\hline Dry matter (DM) & 90.51 & 89.82 & 89.97 \\
\hline Crude protein & 17.76 & 16.59 & 18.43 \\
\hline Crude fibre & 9.27 & 10.62 & 12.33 \\
\hline Ether extract & 3.42 & 2.31 & 1.71 \\
\hline Ash & 4.82 & 6.44 & 7.50 \\
\hline Forage unit for lactation (UFL/kg DM) & 0.98 & 0.98 & 0.97 \\
\hline Protein digestible in the intestine (PDI) & 10.5 & 11.0 & 11.5 \\
\hline \multicolumn{4}{|l|}{ Proximate Fatty Acid Composition (\%) } \\
\hline C8:0-C14 & 1.54 & 3.12 & 4.54 \\
\hline C16:0 & 31.4 & 23.6 & 26.3 \\
\hline C16:1 & 1.04 & 0.63 & 0.62 \\
\hline C18:0 & 11.8 & 9.70 & 10.7 \\
\hline $\mathrm{C} 18: 1 \mathrm{n}-9$ cis & 34.1 & 23.3 & 19.3 \\
\hline $\mathrm{C} 18: 2 \mathrm{n}-6$ cis & 48.3 & 34.8 & 28.2 \\
\hline C18:3 n-6 & 0.18 & 0.18 & 0.44 \\
\hline C18:3 n-3 & 2.92 & 3.81 & 4.12 \\
\hline$\sum$ SFA & 44.7 & 36.4 & 41.5 \\
\hline$\sum$ MUFA & 35.1 & 24.0 & 19.9 \\
\hline$\sum$ PUFA & 51.4 & 38.8 & 32.8 \\
\hline
\end{tabular}

${ }^{1}$ DOP-0, a diet composed of commercial concentrates and alfalfa hay; DOP-40, a diet composed of concentrate and alfalfa hay with $40 \%$ of concentrate cereals replaced by pellets of dehydrated orange pulp; and DOP-80, a diet composed of concentrate and alfalfa hay with $80 \%$ of concentrate cereals replaced by pellets of dehydrated orange pulp. ${ }^{2}$ Nutral cabras LD granulado, Cargill ${ }^{\circledR}$. SFA: saturated fatty acids; MUFA: monounsaturated fatty acids; PUFA: polyunsaturated fatty acids; UFL: Forage Unit for Lactation. 
After parturition, kids remained with their dams from birth to weaning with free access to goat milk all day. All the kids were only fed with maternal milk until slaughtered. Ten male suckling kid goats were selected randomly from each experimental group and slaughtered at an average weight of $8.90 \mathrm{~kg}( \pm 0.17)$ and $32( \pm 1.5)$ days old.

\subsection{Sampling and Chemical Analysis of Diet and Mother's Milk}

For each diet, samples of hay $(2.5 \mathrm{~kg})$ and concentrate $(2 \mathrm{~kg})$ were prepared for analysis by mixing equal amounts of three subsamples collected during the suckling period (at 10, 20 and 30 days after birth). The samples were stored at $-4{ }^{\circ} \mathrm{C}$. Samples of experimental diets were ground to pass a $1 \mathrm{~mm}$ screen in a cyclone mill (Foss) before analysis. The diet components were determined using AOAC methods, as follows: dry matter (method 934.01), ash (method 942.05), ether extract (method 920.39), N (method 984.13), and crude fibre (method 978.10) [9]. The $\mathrm{N}$ values were determined by the Kjeldahl procedure in a 2200 Kjeltec auto-distillation unit (FossTecator, Höganäs, Sweden) and converted to crude protein by multiplying by a factor of 6.25 . Fat content was measured by extraction with petroleum ether (boiling point, $40-60^{\circ} \mathrm{C}$ ) using a Soxtec System HT 1043 Extraction Unit (Foss Tecator, Sweden). The crude fibre was analysed using a Fibertec 2010 Hot Extraction Unit (Foss Tecator, Sweden). The forage units for lactation (UFL) and protein digestible in the small intestine (PDI) were calculated using the Feed Ration Balancer (Format Solutions) software tool, version 2.0 (2017; Cargill, Inc., Minneapolis, MN, USA; www.formatsolutions.com).

Milk was sampled twice during the suckling period (third and fourth week post-partum) and representative samples were taken from each dam. Samples were deposited in iceboxes, sent to the laboratory, and stored at $-20{ }^{\circ} \mathrm{C}$ until they were analysed. The traits of milk samples (dry matter, protein, and fat content) taken during the suckling period were estimated by near-infrared spectroscopy with a Foss NIRSystems 6500 SY-I monochromator (FOSS-NIR Systems Inc., Silver Spring, MD, USA) according to Delgado-Pertíñez et al. [10]. The metabolisable energy (ME) concentration was estimated according to Nsahlai et al. [11].

\subsection{Slaughter Procedures and Muscle Sampling}

The suckling kids were slaughtered using standard commercial procedures according to the guidelines of Council Regulation (EC) $\mathrm{N}^{\circ} 1099 / 2009$ [12] on the protection of animals at the time of killing. After refrigeration for $24 \mathrm{~h}$ at $4{ }^{\circ} \mathrm{C}$, the carcasses were weighed and cut into halves along the midline. The $\mathrm{pH}$ values in the longissimus lumborum (LL) muscle at the 4th and 5th lumbar vertebra were measured using a pH meter (Crison 507; Crison Instruments, Barcelona, Spain) equipped with a penetrating glass electrode. The meat colour was measured at the same time and location as the $\mathrm{pH}$ readings. The colour was determined as the mean of three measurements taken directly on the LL surface after removing any other connective tissue with a scalpel. The colour measurement process included one hour of blooming using a Konica Minolta CM colorimeter (Konica Minolta Inc., Tokyo, Japan) in the CIELAB colour space [13] with a standard illuminant D65, an observation angle of $10^{\circ}$, and zero and white calibration. The lightness $\left(\mathrm{L}^{*}\right)$, redness $\left(\mathrm{a}^{*}\right)$ and yellowness $\left(\mathrm{b}^{*}\right)$ of the meat were

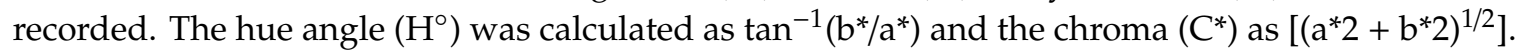

The left half of the carcass was transported to the meat quality laboratory of Huelva University and the shoulder was dissected to obtain the triceps brachii (TB) muscle. The chemical composition of the TB muscle was determined by duplicate according to standard AOAC methods [9] and expressed on a wet basis: the moisture content by method 24,003, the intramuscular fat content by method 13,032, the nitrogen content by method 2057, and the ash content by method 14,066.

After removing the rib cut, the longissimus thoracis (LT) muscle was extracted and two portions of muscle (5 $\mathrm{g}$ each) were used to determine the water-holding capacity (WHC) of meat according to Guzmán et al. [14]. The WHC was expressed as the percentage of expelled juice after compression. The rest of the muscle was vacuum packed and frozen at $-20{ }^{\circ} \mathrm{C}$ until further analysis. 
After thawing the LT muscle under chilled conditions $\left(4^{\circ} \mathrm{C}\right)$ for $24 \mathrm{~h}$, the cooking loss, Warner-Brätzler shear force (WBSF), and haem pigment content were analysed [15]. The haem pigment concentration was calculated using a physical-chemical method expressed as mg myoglobin/g fresh meat. To determine the cooking loss, a portion of caudal slices of vacuum-packed LT was weighed and heated in a $75^{\circ} \mathrm{C}$ water bath to an internal temperature of $70{ }^{\circ} \mathrm{C}$ and monitored with a Jenway thermocouple equipped with a probe (Hanna Instruments HI 8757). The cooking loss was calculated as the difference between the weight of the loin portion before packaging and its weight after cooking, expressed as a percentage [16]. The Cooking loss test samples were then used to determine the WBSF using a Stevens QTS 25 texture analyser equipped with a Warner-Brätzler device [14]. The slices were then cut into samples with a cross-section of $1 \mathrm{~cm}^{2}$ parallel to the muscle fibres. The maximum shear force $\left(\mathrm{kg} / \mathrm{cm}^{2}\right)$ was assessed parallel to the muscle fibres in at least three subsamples of heated meat pieces.

\subsection{Fatty Acid Analysis}

The FA profile of the feed and milk was determined via gas chromatography according to conditions reported by Gutiérrez-Peña et al. [17]. FA methyl esters were separated and quantified using a gas chromatograph (Agilent 6890N Network GS System, Agilent, Santa Clara, CA, USA) equipped with a flame-ionisation detector (FID), an HP 7683 automatic sample injector, and an HP-88 J\&W fused silica capillary column (100 m, 0.25 mm i.d., 0.2- $\mu \mathrm{m}$ film thickness; Agilent Technologies Spain, S.L., Madrid, Spain). The FA profile of intramuscular fat from LT muscle was analysed according to Horcada et al. [18] using a chromatograph (GC, Agilent 6890N, Inc., Santa Clara, CA, USA) equipped with a FID and fitted with a BPX-70 capillary column (120 m, $0.25 \mathrm{~mm}$ i.d., $0.2 \mu \mathrm{m}$ film thickness, SGE, Postnova Analytics Inc., Salt Lake City, UT 84102, USA). The chromatographic conditions were as follows: the initial column temperature was $100^{\circ} \mathrm{C}$, programmed to increase at a rate of $3^{\circ} \mathrm{C} / \mathrm{min}$ up to $158^{\circ} \mathrm{C}$ and then at $1.5^{\circ} \mathrm{C} / \mathrm{min}$ up to $190{ }^{\circ} \mathrm{C}$, maintaining this temperature for $15 \mathrm{~min}$, then at $2{ }^{\circ} \mathrm{C} / \mathrm{min}$ up to $200^{\circ} \mathrm{C}$ and at $10^{\circ} \mathrm{C} / \mathrm{min}$ up to a final temperature of $240^{\circ} \mathrm{C}$, which was maintained for $10 \mathrm{~min}$. The injection and detector temperatures were maintained at $300^{\circ} \mathrm{C}$ and $320^{\circ} \mathrm{C}$, respectively. Hydrogen was used as a carrier gas at a flow rate of $2.7 \mathrm{~mL} / \mathrm{min}$. Fatty acid methyl esters in hexane $(1 \mu \mathrm{L})$ were automatically injected into the column with a split ratio of 17.7:1. Individual FAs were identified using standards (Sigma Chemical Co. Ltd., Poole, UK), expressed as mg FA/100 mg fresh meat, and grouped as follows: saturated (SFA), monounsaturated (MUFA) and polyunsaturated (PUFA). The atherogenicity index (AI) [C12:0 $+4 \times 14: 0+\mathrm{C} 16: 0] /[M U F A+P U F A]$ and the thrombogenicity index (TI) $[$ C14:0 + C16:0 + C18:0]/[0.5 $\times$ MUFA + 0.5 × n-6 PUFA + $3 \times$ n-3 PUFA + (n-3 PUFA/n-6 PUFA)] were calculated according to Ulbricht and Southgate [19].

\subsection{Volatile Compound Analysis}

Slices of the LT muscle were stored overnight at $4{ }^{\circ} \mathrm{C}$ before analysis and were cooked separately at $200{ }^{\circ} \mathrm{C}$ under a mixed closed griddle (Jatta Electro, GR266 1000W, Abadiano, Vizcaya, Spain). The grill was switched on for $15 \mathrm{~min}$ before the sample was grilled. Each sample was placed in the middle of the grilling tray to ensure uniform grilling and was cooked to a core temperature of $70^{\circ} \mathrm{C}$ [20]. Directly after cooking, the meat and all the fat released during cooking were chopped finely in an electric bowl chopper (Janke and Kunkel A-10, IKA Labortechnik, D-79219 Staufen, Germany). Approximately $10 \mathrm{~g}$ of the sample was analysed. Volatile compounds were extracted via the dynamic headspace technique [21]. Immediately after chopping, the samples were placed in a headspace vial (Tekmar, $100 \mathrm{~mL}$ ). The vial was attached to a purge-and-trap sample concentrator (model 4460A, OI Analytical, College Station, TX, USA) and was heated in an external heater set to $70^{\circ} \mathrm{C}$. Volatile compounds were separated in an HP-6890 gas chromatograph (Hewlett-Packard, Madrid, Spain) connected to an HP-5973 quadrupole mass spectrometer (Hewlett-Packard, Madrid, Spain) using an HP-5 capillary column (5\% phenyl methyl siloxane; $50 \mathrm{~m} \times 320 \mu \mathrm{m}$ i.d. $\times 1.05 \mu \mathrm{m}$ film thickness) (Hewlett-Packard, Madrid, Spain) with helium as the carrier gas [21]. A series of n-alkanes (C5-C18, HP5080-8768) in diethyl ether was 
analysed under the same conditions to obtain retention index (RI) values for each volatile compound according to the following equation [22]: $\mathrm{RI}=100 z+100(\mathrm{RT} i-\mathrm{RT} z)(\mathrm{RT} z+1-\mathrm{RT} z)$ where RI is the retention index of the unknown peak, $\mathrm{RT} i$ is the retention time for the unknown peak, RT $z$ and $\mathrm{RT} z+1$ are the retention times for the n-alkanes that bracket the unknown peak, and $z$ is the number of carbon atoms in the n-alkane standard that elute just before the unknown peak.

Compounds were identified by comparing their mass spectra with those contained in the Wiley 275 Library Mass Spectral Database or in previously published literature. Wherever possible, compound identities were confirmed by comparing their RI values with either authentic standards or published values. Retention indices (IDB-5) were calculated using a modified version of the method for temperature-programmed gas chromatography [23]. The peak area of the volatile compounds was integrated from specific ions for each molecule to avoid overlapping between compounds. The integrations were performed using the Chemstation software tool (Hewlett-Packard, Palo Alto, CA, USA).

\subsection{Sensorial Evaluation}

For the sensorial analysis, the left legs of suckling kid goats were used once thawed under chilled conditions $\left(4^{\circ} \mathrm{C}\right)$ for $24 \mathrm{~h}$. The samples were evaluated by 30 untrained panellists consisting of members over the age of 18 years from 10 families (three panellists from each family). Each family received one leg from each diet treatment (DOP-0, DOP-40, and DOP-80) and each of the three family members who participated in the study evaluated the leg from each treatment according to a repeated measures design ( $n=90$ ratings). According to the recommendations for cooking samples, the legs were prepared with olive oil and salt in a standard oven set to $220{ }^{\circ} \mathrm{C}$ for $60 \mathrm{~min}$. The sensorial analysis was carried out according to the method described by Martínez-Cerezo et al. [24]. The following attributes were rated on a 10-point scale: tenderness, juiciness, flavour quality, and overall appraisal. The tenderness was rated from $1=$ very tough to $10=$ very tender; juiciness from $1=$ not at all juicy to 10 = very juicy; and flavour quality from $1=$ very bad to $10=$ very good. The overall appraisal was rated from 1 = very bad to $10=$ very good.

\subsection{Statistical Analysis}

Each parameter of the meat quality was analysed with ANOVA procedures. Normality and homoscedasticity assumptions were rejected for many variables according to the Shapiro-Wilk and Levene tests. Therefore, we chose to use a permutation test using the F-statistic computed in the parametric ANOVA. Under the null hypothesis, in which it is assumed that the "goat feed" factor had no effect, it is equally likely that any of the individual factor labels could be associated with any of the samples. Therefore, if the groups do not differ, another possible value of the test statistic under the null hypothesis may be obtained by randomly shuffling the group labels. In the permutation test, this random shuffling is repeated a large number of times (B) to obtain B values for the test statistic. A $p$ is computed as the proportion of the $B$ values that are greater than or equal to the observed $F$ statistics in the data set. In this study, 999 permutations were performed $(B=999)$. This procedure was carried out with the adonis function in the R-vegan package [25].

The statistical model used in the ANOVA included the fixed effects of the feeding regime and the random effect of the individual. The following model was used:

$$
\mathrm{Y}_{\mathrm{ik}}=\mu+\mathrm{FR}_{\mathrm{i}}+\mathrm{e}_{\mathrm{ik}}
$$

where $Y_{i k}$ is $\mathrm{pH}$, moisture, protein, fat, ash content, shear force, WHC, cooking loss, $\mathrm{L}^{*}, \mathrm{a}^{*}, \mathrm{~b}^{*}, \mathrm{C}^{*}, \mathrm{H}^{0}$, FA profiles of intramuscular fat, and volatile compounds in meat; $\mu$ is the least squares mean value; $\mathrm{FR}_{\mathrm{i}}$ is the fixed effect of feeding regimes ( $\mathrm{i}=1$ : DOP- $0 ; \mathrm{i}=2$ : DOP-40; $\mathrm{i}=3$ : DOP-80); and $\mathrm{e}_{\mathrm{ik}}=$ random residual effect. 
The goats' proximal chemical composition, ME, and FA composition for milk during the suckling period were analysed with the repeated measures procedure. The model included the fixed between-subjects factor of dietary treatment, the fixed within-subjects factor of the week of lactation (repeated measures), and the interactions between these factors. The linear model used for each parameter was as follows:

$$
\text { Yijk }=\mu+\mathrm{Ti}+\mathrm{Aij}+\mathrm{Wk}+(\mathrm{T} \times \mathrm{W}) \mathrm{ik}+\varepsilon \mathrm{ijk}
$$

where Yijk $=$ observations for dependent variables; $\mu=$ overall mean; $\mathrm{Ti}=$ effect of diet treatment; $\mathrm{Aij}=$ random effect of animal $\mathrm{j}$ for the $\mathrm{i}$ treatment; $\mathrm{Wk}=$ effect of the $\mathrm{k}$ week of lactation; $\mathrm{T} \times \mathrm{W}=$ interactions among these factors for the $\mathrm{i}$ treatment and $\mathrm{k}$ week of lactation, and $\varepsilon \mathrm{ijk}=$ random effect of residual. However and for simplification, the results for the factor week of lactation have not been presented in this paper.

For each sensorial property, we have computed the average value of the three evaluations provided by the three members of a family. This way, a data matrix is formed with 10 rows (10 families) and three columns (three feeding regimes). Therefore, this data matrix reflects a repeated measures design, as each family offers data to the three regimes. This design suggests the performance of a profile analysis [26] to evaluate the equality of the three population means for the three feeding regimes. The null hypothesis for this two-dimensional variable is that the three population means equal zero, which would mean that the three population means for the three feeding regimes are equal. This null hypothesis about the transformed variables has been tested with the HotellingsT2 function in the ICSNP $\mathrm{R}$ library. A random vector $\left(\mathrm{X}_{1}, \mathrm{X}_{2}, \mathrm{X}_{3}\right)$ is defined where $\mathrm{Xi}$ denotes the average value of the three evaluations provided by the three members of a family for feeding regime $i$. Therefore, if we call $\mu 1$, $\mu 2$ and $\mu 3$ the population mean of $X i$, the profile analysis will test the null hypothesis $\mu 1=\mu 2=\mu 3$. Previously, multivariate normality was assessed with the Mardia test, a generalisation of the univariate tests based on the skewness and kurtosis measures [26]. Both measures showed no statistical difference from the values assumed in the multivariate normality scenario. To identify different mean values, three comparisons of two matched samples were performed with the $\mathrm{t}$-test function in $\mathrm{R}$ and a Bonferroni correction was considered $(p<0.05)$.

Finally, a linear discriminant analysis was conducted with variables that were significantly different to discriminate between the three feeding regimes. The linear discriminant analysis function in the MASS package in R was used [27].

\section{Results and Discussion}

There were no significant differences between the diet treatments in terms of birth weight, slaughter live weight, and cold carcass weight of suckling kids (on average $2.84 \mathrm{~kg}, 3.06 \mathrm{~kg}$, and $2.95 \mathrm{~kg} ; 8.98 \mathrm{~kg}$, $9.03 \mathrm{~kg}$, and $8.65 \mathrm{~kg} ; 4.74 \mathrm{~kg}, 4.82 \mathrm{~kg}$, and $4.65 \mathrm{~kg}$, for DOP-0, DOP-40 and DOP-80, respectively; unpublished data). The cold carcass weights ranged from $4.65 \mathrm{~kg}$ to $4.82 \mathrm{~kg}$ and are in line with commercial carcass weights in the southern European market [16].

The mean values of chemical composition and FA profile of mother's milk from two samples are shown in Table 2.

Mother diet had no significant effect on milk yield (the average daily milk yield and the total yield during the suckling period were $1.6 \mathrm{l} / \mathrm{d}$ and $60 \mathrm{l}$, respectively; unpublished data), chemical components, or ME, except for fat $(p<0.05$; Table 2$)$, which was significantly higher for the DOP-40 diet than for the DOP-80 diet (the DOP-0 diet was not significantly different than the other two diets). Although increased milk fat content is common when dietary fiber concentrations rise at the expense of starch [28], small differences were found in our study, probably due to the small differences in fibre content between the three diets. Furthermore, we observed significant effects of diet treatment on the FA profile (Table 2) for only two acids: C18:0 ( $p<0.001$; higher for the DOP- 0 diet than DOP-80 diet, while the DOP-40 diet did not differ from the other two diets) and C20: 4 n-6 ( $p<0.05$; higher for DOP-40 diet than DOP-0 
diet, while the DOP-80 diet did not differ from the other two diets). Concerning C18:0, the higher percentage of this acid in the DOP-0 diet (Table 1) may explain its increased abundance in DOP-0 milk.

Table 2. Chemical composition and fatty acid (FA) content (expressed as mg/g dry matter) of mother's milk (mean values of the two samples) during the natural suckling period by experimental diet type ${ }^{1}$.

\begin{tabular}{|c|c|c|c|c|c|}
\hline Item $^{3}$ & DOP-0 & DOP-40 & DOP-80 & SEM $^{2}$ & $p$-Values \\
\hline No. of goats & 10 & 10 & 10 & & \\
\hline Dry matter (\%) & 13.14 & 12.95 & 12.56 & 0.254 & 0.757 \\
\hline Fat matter $(\%)$ & $4.94^{\mathrm{a}, \mathrm{b}}$ & $5.33^{\mathrm{a}}$ & $4.31^{b}$ & 0.135 & 0.027 \\
\hline Crude protein $(\%)$ & 3.89 & 4.20 & 3.82 & 0.094 & 0.107 \\
\hline $\mathrm{ME}(\mathrm{MJ} / \mathrm{kg})$ & 3.44 & 3.54 & 3.25 & 0.054 & 0.108 \\
\hline$\sum$ SFA & 206.39 & 207.17 & 201.79 & 2.611 & 0.401 \\
\hline C8:0-C13:0 & 56.35 & 58.92 & 58.49 & 0.836 & 0.370 \\
\hline C14:0 & 29.80 & 30.53 & 29.58 & 0.453 & 0.252 \\
\hline C16:0 & 69.90 & 70.20 & 68.67 & 0.928 & 0.672 \\
\hline C18:0 & $31.49^{\mathrm{a}}$ & $29.68^{a, b}$ & $27.28^{b}$ & 0.505 & 0.001 \\
\hline$\sum$ MUFA & 70.45 & 68.85 & 64.89 & 1.026 & 0.083 \\
\hline C16:1 & 3.36 & 3.47 & 3.36 & 0.087 & 0.657 \\
\hline Total C18:1 & 64.64 & 63.07 & 59.33 & 0.972 & 0.177 \\
\hline$\sum$ PUFA & 16.83 & 16.29 & 15.60 & 0.311 & 0.314 \\
\hline Total C18:2 n-6 & 11.45 & 11.15 & 10.86 & 0.280 & 0.736 \\
\hline C18:3 n-3 & 0.91 & 0.94 & 0.94 & 0.027 & 0.580 \\
\hline C20:2 & 0.15 & 0.16 & 0.15 & 0.005 & 0.160 \\
\hline$C 20: 3 n-6$ & 0.18 & 0.18 & 0.16 & 0.007 & 0.079 \\
\hline C20:4 n-6 & $0.08^{b}$ & $0.10^{\mathrm{a}}$ & $0.09^{a, b}$ & 0.003 & 0.014 \\
\hline C20:5n-3 & 0.36 & 0.35 & 0.35 & 0.006 & 0.784 \\
\hline$C 22: 5 n-3$ & 0.40 & 0.40 & 0.37 & 0.009 & 0.264 \\
\hline$C 22: 6 n-3$ & 0.41 & 0.39 & 0.36 & 0.011 & 0.323 \\
\hline Others FA & 24.20 & 22.78 & 22.30 & 0.417 & 0.204 \\
\hline PUFA/SFA & 0.08 & 0.08 & 0.08 & 0.001 & 0.343 \\
\hline n-6/n-3 & 5.42 & 5.27 & 5.29 & 0.166 & 0.552 \\
\hline AI & $2.34^{b}$ & $2.47^{\mathrm{a}, \mathrm{b}}$ & $2.55^{\mathrm{a}}$ & 0.023 & 0.101 \\
\hline TI & 2.72 & 2.76 & 2.80 & 0.020 & 0.390 \\
\hline
\end{tabular}

Different superscripts $\left({ }^{\mathrm{a}, \mathrm{b}}\right)$ indicate significant differences $(p<0.05)$ among treatments. ${ }^{1}$ See Table $1 ;{ }^{2}$ Standard error of mean; ${ }^{3}$ SFA: saturated fatty acids; PUFA: polyunsaturated fatty acids; AI: atherogenicity index; TI: thrombogenicity index; ME: metabolisable energy.

\subsection{Chemical Analysis and Physical Properties of the Meat}

The chemical and physical characteristics of the meat are shown in Table 3. The $\mathrm{pH}$ values found were in line with several studies [14,29] and higher than those reported by Ripoll et al. [16] ( $\mathrm{pH}$ values around 5.70) for European goat breeds. High ultimate $\mathrm{pH}$ values for goat muscles are common in the literature, suggesting that, unlike other species such as sheep and cattle, kids are generally highly prone to stress [30]. In the present study, no significant differences $(p>0.05)$ between the three treatments were observed in meat $\mathrm{pH}$ values after 24 hours. The use of $\mathrm{DOP}$ in the goat feed does not seem to affect the $\mathrm{pH}$ values of the kid meat, and so alterations to the properties of the meat during maturation are not expected.

The values for the chemical composition of the meat were within the ranges described by Guzmán et al. [14] in Payoya kids and Ripoll et al. [16] for kids of native Mediterranean goat breeds. The chemical analysis of the kid goat meat (Table 3) did not reveal significant differences between the treatments in terms of moisture, protein, fat, or ash content $(p>0.05)$. There were also no significant differences in the main descriptors of goat milk composition between the three diet groups (Table 2). 
Table 3. Chemical composition of triceps brachii muscle and instrumental traits of longissimus muscle of suckling goat kids, according to the use of dehydrated orange pulp in feeding dams ${ }^{1}$.

\begin{tabular}{|c|c|c|c|c|c|}
\hline Chemical and Physical Characteristics & DOP-0 $(n=10)$ & DOP-40 $(n=10)$ & DOP-80 $(n=10)$ & SEM $^{2}$ & $p$ \\
\hline $\begin{array}{c}\mathrm{pH}_{24 h o u r s} \\
\text { Chemical composition (\% fresh meat) }\end{array}$ & 5.93 & 5.89 & 6.10 & 0.045 & 0.219 \\
\hline Moisture & 77.13 & 77.48 & 77.12 & 0.239 & 0.843 \\
\hline Protein & 18.68 & 18.54 & 18.57 & 0.195 & 0.981 \\
\hline Fat & 1.99 & 1.83 & 1.95 & 0.059 & 0.486 \\
\hline Ash & 1.24 & 1.28 & 1.34 & 0.034 & 0.545 \\
\hline Shear force $\left(\mathrm{kg} / \mathrm{cm}^{2}\right)$ & 5.93 & 5.36 & 6.56 & 0.213 & 0.074 \\
\hline Water loss (\% fresh meat) & & & & & \\
\hline Expelled juice & 17.13 & 16.47 & 16.15 & 0.407 & 0.630 \\
\hline $\begin{array}{l}\text { Cooking loss } \\
\text { Colour }\end{array}$ & 25.76 & 25.68 & 24.04 & 0.648 & 0.492 \\
\hline Myoglobin content (mg/g fresh meat) & 2.42 & 2.23 & 2.63 & 0.169 & 0.520 \\
\hline Lightness $\left(\mathrm{L}^{*}\right)$ & $56.19^{\text {a }}$ & $53.94^{\mathrm{b}}$ & $53.14^{\mathrm{b}}$ & 0.424 & 0.004 \\
\hline Redness ( $\left.a^{*}\right)$ & $4.52^{b}$ & $6.30^{\mathrm{a}}$ & $5.83^{\mathrm{a}}$ & 0.237 & 0.029 \\
\hline Yellowness $\left(b^{*}\right)$ & 7.40 & 6.06 & 6.66 & 0.282 & 0.054 \\
\hline Chroma $\left(\mathrm{C}^{*}\right)$ & 8.80 & 9.23 & 8.61 & 0.256 & 0.367 \\
\hline Hue angle $\left({ }^{0}\right)$ & $58.03^{\mathrm{a}}$ & $44.81^{\mathrm{b}}$ & $48.26^{\mathrm{b}}$ & 1.856 & 0.013 \\
\hline
\end{tabular}

Different superscripts $\left({ }^{(a, b}\right)$ indicate significant differences $(p<0.05)$ among treatments. ${ }^{1}$ See Table $1 ;{ }^{2}$ SEM: standard error of the mean.

Meat tenderness is one of the most important attributes for consumer satisfaction. All the meat samples had shear force values in a similar range to the values reported by Marichal et al. [2] ( 5.5 to $8.1 \mathrm{~kg} / \mathrm{cm}^{2}$ ) for suckling kid goats slaughtered at similar weights and fed exclusively with milk, which are representative of the kid goat market in Mediterranean Europe. The mother's diet did not significantly affect shear force values in the kids' LT muscles (Table 3). We found no significant difference $(p>0.05)$ between the groups in WHC, measured as expelled juice and cooking loss (Table 3 ). These observations are in line with Caparra et al. [7], who did not observe a dramatic effect on the main physical properties of meat after incorporating dried citrus pulp into the diet of lambs.

With regard to meat colour (Table 3), the meat was observed to have a reduced myoglobin content as compared to adult animals, as corresponds to suckling animals [29]. As the animals' diet consisted exclusively of breast milk and this milk does not contain the iron necessary for myoglobin, it was expected that the meat would exhibit a reduced myoglobin level. In the present study, no differences between the treatment diets $(p>0.05)$ were observed in myoglobin content. Although orange pulp includes trace amounts of iron $(0.009 \mathrm{mg} / 100 \mathrm{~g})$, the lack of a dietary effect on myoglobin may reflect the absence of iron in mother's milk, which makes it necessary to introduce other more iron-rich feeds (such as grass or cereal) to maintain meat myoglobin levels. The instrumental meat colour values were within the ranges observed by other authors using dairy goat kids slaughtered with similar weights [29] (ranges 50.07-56.93, 9.08-11.50 and 36.83-43.99 for $\mathrm{L}^{*}, \mathrm{C}^{*}$ and $\mathrm{H}^{0}$ respectively), while they were lower than those reported in meat from heavier kids from meat goat breeds [16] (ranges 52.95-54.76, 18.05-23.65, and 44.30-59.90 for $\mathrm{L}^{*}, \mathrm{C}^{*}$, and $\mathrm{H}^{0}$ respectively). Mother's diet significantly affected $\mathrm{L}^{*}(p<0.01)$, $\mathrm{a}^{*}$, and $\mathrm{H}^{0}(p<0.05)$ values. The inclusion of DOP in the goats' diet decreased the $\mathrm{L}^{*}$ and $\mathrm{H}^{0}$ parameters of suckling goat meat, which were darker than those observed in the case of traditional diets. In fact, an increase in $a^{*}$ was observed in suckling goat meat when DOP was added to the goat feed. In general, the addition of DOP in the mother's diet can lead to a decrease in the proportions of light pink meat and increase the proportion of darker meat in suckling goat meat.

\subsection{Fatty Acids and Nutritional Properties of the Meat}

While a total of 37 FAs were identified in the LT muscle, only the main FAs are shown in Table 4. In general, the results for the three treatments were within the ranges reported in kids of the Payoya breed [31]. The SFA group was the most prevalent (around 43\% of total FAs detected), while MUFAs 
and PUFAs comprised approximately $32 \%$ and 25\% of total FAs detected, respectively. Similar results have been reported in Spanish breeds of suckling kids [18].

Table 4. Fatty acid (FA) composition of the meat of suckling goat kids (expressed as mg FA/100g fresh meat) according to the use of dehydrated orange pulp in feeding dams ${ }^{1}$.

\begin{tabular}{|c|c|c|c|c|c|}
\hline Item $^{2}$ & DOP-0 $(n=10)$ & DOP-40 $(n=10)$ & DOP-80 $(n=10)$ & SEM $^{3}$ & $p$ \\
\hline$\sum$ SFA & 602.36 & 579.87 & 523.00 & 14.300 & 0.060 \\
\hline C8:0-C13:0 & 7.70 & 7.87 & 6.69 & 7.415 & 0.389 \\
\hline C14:0 & 40.33 & 40.51 & 35.70 & 1.864 & 0.506 \\
\hline C16:0 & 298.92 & 290.67 & 269.73 & 8.146 & 0.332 \\
\hline C18:0 & $229.56^{a}$ & $213.79^{a}$ & $186.41^{b}$ & 4.602 & 0.000 \\
\hline$\sum$ MUFA & $483.3^{\mathrm{a}}$ & $479.8^{\mathrm{a}}$ & $456.5^{b}$ & 13.983 & 0.018 \\
\hline C16:1 & 21.40 & 23.37 & 18.67 & 0.985 & 0.148 \\
\hline Total C18:1 & $404.6^{\mathrm{a}}$ & $393.3^{a b}$ & $371.6^{\mathrm{b}}$ & 12.648 & 0.015 \\
\hline$\sum$ PUFA & 344.63 & 318.23 & 316.95 & 6.405 & 0.137 \\
\hline Total C18:2 n-6 & $159.27^{\mathrm{a}}$ & $135.69^{b}$ & $139.73^{b}$ & 3.526 & 0.009 \\
\hline C18:3 n-3 & 4.72 & 5.10 & 4.50 & 0.127 & 0.148 \\
\hline C20:2 & 21.12 & 19.79 & 18.03 & 0.668 & 0.167 \\
\hline$C 20: 3 n-6$ & $6.63^{a}$ & $5.81^{b}$ & $5.68^{b}$ & 0.155 & 0.020 \\
\hline C20:4 n-6 & 108.55 & 106.64 & 107.36 & 2.637 & 0.959 \\
\hline C20:5n-3 & 5.20 & 5.67 & 4.97 & 0.205 & 0.059 \\
\hline C22:5n-3 & 16.31 & 16.18 & 16.52 & 0.283 & 0.891 \\
\hline $\mathrm{C} 22: 6 \mathrm{n}-3$ & 6.65 & 7.48 & 6.92 & 0.237 & 0.361 \\
\hline Others FA & $214.90^{\mathrm{a}}$ & $191.96^{\mathrm{ab}}$ & $189.32^{b}$ & 4.519 & 0.033 \\
\hline \multicolumn{6}{|c|}{ Ratios to nutritional human health } \\
\hline PUFA/SFA & $0.57^{\mathrm{b}}$ & $0.55^{\mathrm{b}}$ & $0.61^{\mathrm{a}}$ & 0.786 & 0.007 \\
\hline$n-6 / n-3$ & $8.39^{a}$ & $7.06^{b}$ & $7.58^{b}$ & 0.184 & 0.007 \\
\hline AI & 0.59 & 0.59 & 0.61 & 0.009 & 0.660 \\
\hline TI & $1.26^{\mathrm{a}}$ & $1.19^{\mathrm{b}}$ & $1.20^{\mathrm{b}}$ & 0.011 & 0.010 \\
\hline
\end{tabular}

Different superscripts $\left({ }^{\mathrm{a}, \mathrm{b}}\right)$ indicate significant differences $(p<0.05)$ among treatments. ${ }^{1}$ See Table $1 ;{ }^{2}$ SFA: saturated fatty acids; MUFA: monounsaturated fatty acids; PUFA: polyunsaturated fatty acids; AI: atherogenicity index; TI: thrombogenicity index. ${ }^{3}$ SEM: standard error of the mean.

There was no significant difference in SFA content between the treatments $(p>0.05)$, including major saturated palmitic FA (C16:0) (Table 4). Mother's milk is rich in saturated short and medium-chain FAs (mainly C16:0). The use of concentrates rich in orange pulp in the dam's ration had no effect on the C16:0 content of the suckled milk nor on the composition of the kids' meat. Differences in the MUFA content of the kids' meat $(p<0.05)$ were observed among the treatments. In fact, higher C18:1 fatty acid content in meat from the DOP-0 and DOP-40 diets $(p<0.05$; Table 4$)$ were observed. However, we did not observe significant changes in the content of the main unsaturated FA (C18:1) in mother's milk when orange pulp was included in the goats' diet (Table 2). Our results are in line with those of Wang et al. [32], who found higher C18:1 content in the meat of animals raised on cereal-based diets. On the other hand, the lower C18:0 content observed in the meat from DOP-80 kids as compared to the DOP-0 group (Table 4) reflects the fact that the milk of the DOP-80 group had the lowest C18:0 content (Table 2). This observation relates to the idea that the fat composition of the meat of lactating kids depends mainly on the characteristics of the milk they ingest because the ruminal processes of fat biohydrogenation are not evident in lactating animals.

In all the proposed treatments, the PUFA content in the kids' meat was lower than the SFA and MUFA content (Table 4). This observation was expected because the PUFA content of the milk ingested was lower (Table 2) than the SFA and MUFA content. The PUFA content is important in meat because these FAs are highly oxidable during cooking [33]. Moreover, previous studies have indicated that SFAs (e.g., C16:0 and C18:0) and MUFAs (e.g., C18:1) are positively correlated with meat flavour [34], while PUFAs are negatively correlated. The effect of including DOP in the dam diets was insignificant for most PUFAs in the kid goat meat. Only two PUFAs were affected by the diet treatments. In fact, significant decreases of the most important PUFAs, C18:2 $(p<0.01)$ and C20:3 n-6 FA $(p<0.05)$ were observed in meat from diets that included orange pulp. 
Consumers are increasingly interested in the lipid content of edible meat due to its relationship to human health. In a healthy human diet, the PUFA/SFA ratio should be as low as possible to reduce the risk of heart disease, among other health problems [35]. In our study, significant differences were observed in the PUFA/SFA ratio $(p<0.01$; Table 4$)$. The most favourable PUFA/SFA ratio for human health ( 0.60 index) was observed in the case of kid goat meat from treatments using the highest concentration of DOP in the dam's diet (DOP-80). The reduced C18:0 content observed in kid goat meat from the DOP-80 treatment (Table 4) improved the PUFA/SFA ratio. Replacing cereal with DOP reduces the C18:0 content of the meat and therefore reduces the PUFA/SFA ratio.

A relationship between human health and the n-6/n-3 PUFA index has been proposed. Some clinical studies have recommended a n-6/n-3 ratio of less than four in order to reduce the risk of coronary disease [35]. The use of DOP in goat feed had a significant positive effect on the n-6/n-3 ratio (Table 4). The values obtained for the $n-6 / n-3$ ratio in the three diet treatments (range 7.0 to 8.4 ) were higher than those recommended to prevent coronary heart disease. However, replacing cereal with DOP improved the $n-6 / n-3$ ratio $(p<0.01)$ of kid goat meat, which may be due to the decrease of the most prevalent n-6 PUFAs, C18:2 and C20:3 n-6 FA, observed in meat from diets using orange pulp. Recommendations to consume foods with reduced thrombogenicity indices have also been suggested as a measure to improve human health [19]. The thrombogenicity index in the meat of the kids from DOP treatments was lower than that observed in the meat of kids whose goats ingested mainly cereal concentrate (DOP-0) (Table 4). This observation is related to the lower content of C18:0 and the higher content of C20:4 n-6 in the milk of the DOP-40 and DOP-80 mothers (Table 2).

\subsection{Volatile Compounds and Aromatic Properties of Meat}

The flavour of cooked meat play a major role in determining consumers' acceptance of meat and their meat preferences [36]. As is reported in the literature, the analysis of volatile compounds in raw meat is complicated by the low percentage of intramuscular fat distributed heterogeneously in meat [37], as volatile compounds are stored in muscle fat only at trace levels. This observation is especially important for suckling kid goat muscle, as the average fat content is usually less than $2 \%$ in fresh meat. A total of 21 volatile compounds were tentatively identified in grilled goat kid meat for the three diet treatments (Table 5).

All the volatiles that we identified were clustered in the following chemical families: aldehydes (3), aliphatic ketones (4), aliphatic alcohols (1), furans (1), sulphur compounds (4), aliphatic aldehydes (5), aliphatic hydrocarbons (2), and aromatic hydrocarbons (1). Aldehydes were the main chemical family in cooked kid loins (around 55\%), followed in decreasing order by aliphatic ketones, sulphur compounds, aliphatic aldehydes, aliphatic alcohols, furans, aromatic hydrocarbons and aliphatic hydrocarbons (around 19\%, 13\%, 11\%, $0.8 \%, 0.7 \%, 0.4 \%$, and $0.1 \%$, respectively). The main chemical families of the volatile compounds found in this study are in accordance with those reported for cooked meat in the literature [40]. The generation of these volatile compounds in cooked meat is dependent upon the concentration of carbohydrates, amino acids, and lipids in the raw meat and the cooking conditions [37].

The effect of including orange by-products in goat feed was significant in a low number of individual volatile compounds (Table 5), including ethyl furan, dimethyl disulphide, and heptane. No significant differences were observed in other carbonyl compounds, such as unsaturated aldehydes or aliphatic ketones, among the three treatment groups. This observation reflects the small contribution of lipid oxidation to the development of aldehydes and ketones in suckling kid goat meat because of the meat's low fat content. 
Table 5. Volatile compounds of the meat of suckling goat kids (expressed in area unit $\times 10^{6}$ ) according to the use of dehydrated orange pulp in feeding dams ${ }^{1}$.

\begin{tabular}{|c|c|c|c|c|c|c|c|c|}
\hline Volatile Compounds & $\mathbf{I}_{\mathrm{DB}-5}$ & MS & RI & DOP-0 $(n=10)$ & DOP-40 (n = 10) & DOP-80 (n = 10) & SEM & $p$ \\
\hline \multicolumn{9}{|l|}{ Aldehydes } \\
\hline Acethaldehyde & $<500$ & + & + & 24.37 & 28.44 & 30.77 & 1.404 & 0.230 \\
\hline 2-Methyl butanal & 648 & + & + & 5.62 & 6.31 & 7.40 & 0.500 & 0.678 \\
\hline Total $(\%)$ & & & & 54.44 & 55.80 & 54.97 & & \\
\hline \multicolumn{9}{|l|}{ Aliphatic Ketones } \\
\hline 2-Butanone & 601 & + & + & 2.83 & 3.17 & 3.96 & 0.274 & 0.500 \\
\hline n-Nonane & 622 & + & & 0.33 & 0.33 & 0.49 & 0.041 & 0.266 \\
\hline Total $(\%)$ & & & & 19.80 & 18.49 & 19.64 & & \\
\hline \multicolumn{9}{|l|}{ Aliphatic Alcohols } \\
\hline Ethanol & 669 & + & + & 0.61 & 0.67 & 0.80 & 0.100 & 0.857 \\
\hline Total (\%) & & & & 0.83 & 0.83 & 0.88 & & \\
\hline Methanethiol & 1280 & + & + & 7.12 & 8.28 & 8.30 & 0.548 & 0.953 \\
\hline Dimethyl disulfide & 761 & + & + & $1.20^{\mathrm{c}}$ & $1.46^{\mathrm{b}}$ & $2.32^{\mathrm{a}}$ & 0.194 & 0.047 \\
\hline Carbon disulfide & 544 & + & + & 0.18 & 0.20 & 0.18 & 0.009 & 0.142 \\
\hline 2,3,4-Trisulfide & 970 & + & + & 0.81 & 0.80 & 0.76 & 0.130 & 0.961 \\
\hline Total $(\%)$ & & & & 13.09 & 13.05 & 12.83 & & \\
\hline \multicolumn{9}{|l|}{ Aliphatic Aldehydes } \\
\hline 2-Methyl propanal & 905 & + & + & 7.46 & 8.28 & 8.96 & 0.550 & 0.895 \\
\hline Hexanal & 800 & + & + & 0.30 & 0.35 & 0.45 & 0.050 & 0.415 \\
\hline Heptanal & 900 & + & + & 0.22 & 0.14 & 0.14 & 0.027 & 0.665 \\
\hline Octanal & 1002 & + & + & 0.13 & 0.14 & 0.14 & 0.027 & 0.815 \\
\hline Nonanal & 1109 & + & + & 0.05 & 0.07 & 0.04 & 0.018 & 0.764 \\
\hline
\end{tabular}

Different superscripts $\left({ }^{\mathrm{a}, \mathrm{b}}\right)$ indicate significant differences $(p<0.05)$ among treatments; nd: not detected. $I_{\text {DB-5 }}$ : retention index as determined using hydrocarbons on an HP-5 fused silica column. MS: tentatively identified by matching the simple spectrum against the Wiley 275 library spectrum; RI: approximate identification by comparing the retention index with literature values $[38,39] ;{ }^{1}$ See Table 1 . SEM: standard error of the mean.

Including orange pulp in the dams' feed caused significant differences $(p<0.05)$ in the ethyl furan content of kid meat (Table 5), as the highest values were observed in kid steaks from DOP-40 and DOP-80 $\left(0.20\right.$ and $\left.0.30 \mathrm{AU} \times 10^{6}\right)$. Furan is mainly associated with an aroma described as sweet and caramel-like [36]. Limacher et al. [41] found that the main formation pathways for furans are from the intact sugar skeleton of fruit. Under the roasting conditions used in our study, furans would mainly be formed from the intact sugar skeleton (mainly hexoses) of the orange pulp. Including DOP in goat feed also affected the meat's sulphur compounds, causing significant differences $(p<0.05)$ in dimethyl disulphide in cooked suckling kid goat meat (Table 5), with the highest amounts of dimethyl disulphide occurring in kid goat steaks from DOP-80 $\left(2.32 \mathrm{AU} \times 10^{6}\right)$. While DOP is rich in sulphur compounds $(0.11 \% /$ dry weight), the sulphur compound content of cereals varies [42]. Sulphur compounds were found to contribute to the meat odour of lambs [43], but there are no cases in the literature regarding sulphur compounds in suckling kid goat meat. Farmer et al. [44] found that sulphur compounds in meat are products of reactions involving sulphur-containing amino acids. Therefore, it is to be expected that the meat of kids from goats fed with DOP would have a higher content of sulphur-containing amino acids than the meat of kids from goats fed using cereal diets.

Madruga et al. [45] reported that hexanal is an important aldehyde in the aroma of goat meat. Aldehydes are derived from the lipid-oxidation Maillard reaction and the breakdown of amino acids through transamination and decarboxylation [46]. In fact, during cooking, hexanal is derived from 
the thermal degradation of $\mathrm{C} 18: 1$. The lower C18:1 content observed in the meat of the goats from the DOP diet groups does not seem to have resulted in differences in meat hexanal content between the three treatment groups. A significant decrease in C18:1 content ( $p=0.015$; Table 4$)$ was observed when increasing DOP in the ration of the mothers, while diet treatment was not observed to have a significant effect on hexanal content ( $p>0.05$; Table 5$)$. This observation may relate to the low fat content in the meat of the suckling kids in all three treatment groups.

Aliphatic hydrocarbons are especially important for the typical aroma of meats and contribute to the characteristic flavour of several animal species [47]. With regard to these compounds, the highest heptane content $(p<0.05$, Table 5$)$ was observed in suckling kid goat meat from DOP-80. Elmore et al. [48] suggested that a diet high in PUFAs leads to an increase in heptane in grilled lamb meat. However, this relationship was not evident in the case of the kid goats used in the present study, since no significant effect of PUFA content in mother's milk on heptane levels was observed (Table 2). The three diet treatments also had no significant effect on PUFA content in kid meat. It is likely that these results are related to the low fat content of the kid meat.

\subsection{Sensorial Properties of Meat}

The untrained panellists' perceptions of the acceptability of suckling kid goat meat depending on the mother goat's diet are shown in Table 6. In general, the scores ranged between seven and eight on a 10-point scale measuring tenderness, juiciness, flavour quality, and overall appraisal of the meat.

Table 6. Evaluations of the tenderness, juiciness, flavour quality, and overall quality of the meat of suckling goat kids by untrained panellists, according to the use of dehydrated orange pulp in feeding dams ${ }^{1}$.

\begin{tabular}{cccccc}
\hline Sensory Attributes & DOP-0 $(\mathbf{n}=\mathbf{1 0})$ & DOP-40 $(\mathbf{n}=\mathbf{1 0})$ & DOP-80 $(\mathbf{n}=\mathbf{1 0})$ & SEM & $p$ \\
\hline Tenderness & 7.37 & 7.43 & 7.56 & 0.548 & 0.344 \\
Juiciness & 7.19 & 7.40 & 7.53 & 0.414 & 0.171 \\
Flavour quality & $7.10^{\mathrm{b}}$ & $7.53^{\mathrm{a}}$ & $7.77^{\mathrm{a}}$ & 0.606 & 0.007 \\
Overall appraisal & 7.17 & 7.59 & 7.72 & 0.619 & 0.074 \\
\hline
\end{tabular}

Different superscripts $\left({ }^{\mathrm{a}, \mathrm{b}}\right)$ indicate significant differences $(p<0.05)$ among treatments. ${ }^{1}$ See Table 1. SEM: standard error of the mean.

There was no specific preference between diet treatments concerning the tenderness or juiciness of the meat because the animals were young and the meat in all the treatments was tender and juicy ( $p>0.05$, Table 6). This result may be related to the fact that no significant differences were observed among the three treatments for the shear force or water losses of the meat (Table 3). However, the flavour quality of the meat was influenced by the dam's feed $(p<0.01)$. Meat from treatments including DOP was considered to have a more desirable flavour than the meat from the cereal-based diet (Table 6). There was no general agreement regarding the desirability of the flavours. There was considerable disagreement among the subjects about this factor. However, consumers from a specific geographic area tended to like the same kind of meat, probably due to the influence of previous experiences or the gastronomic culture in local areas, which are partially determined by the products available on the market [24].

Fat content can affect the aromatic characteristics of meat. However, no significant differences were observed among the three diet treatments in terms of the fat content of suckling kid goats (Table 3). Accordingly, the fat content of the meat should not be considered to have been a factor in the untrained panellists' evaluation. Alternatively, the higher flavour values likely relates to the specific content of aromatic compounds detected in the meat. Resconi et al. [49] identified several volatile sulphur compounds that contribute to the development of meat flavour. In our study, the highest content of dimethyl disulphide was observed in kid goat meat from treatments that included DOP in the goat feed (Table 5). Dimethyl disulphide is a volatile compound derived from the oxidation and degradation of cysteine and methionine (sulphuric amino acids) that can be aromatically detected at low concentrations [49]. Ethyl furan and aliphatic hydrocarbons such as heptane could also contribute 
to the differences in flavour quality reported by the untrained panellists (these compounds occurred at the highest levels in meat from the DOP treatments).

Many individual sensory attributes influence the acceptability of meat (e.g., juiciness, colour, greasiness, etc.). However, an overall appraisal provides an idea of whether the consumers liked the meat. The effect of including DOP in the dam's feed on the overall acceptability of kid goat meat was insignificant (Table 6). The low fat content in suckling kid goats is likely to have influenced this assessment for untrained panellists.

\subsection{Discriminant Analysis}

A linear discriminant analysis model was built to determine the relationship between groups of variables and the three feeding groups for datasets that were significantly different of suckling kid goat meat (Figure 1).

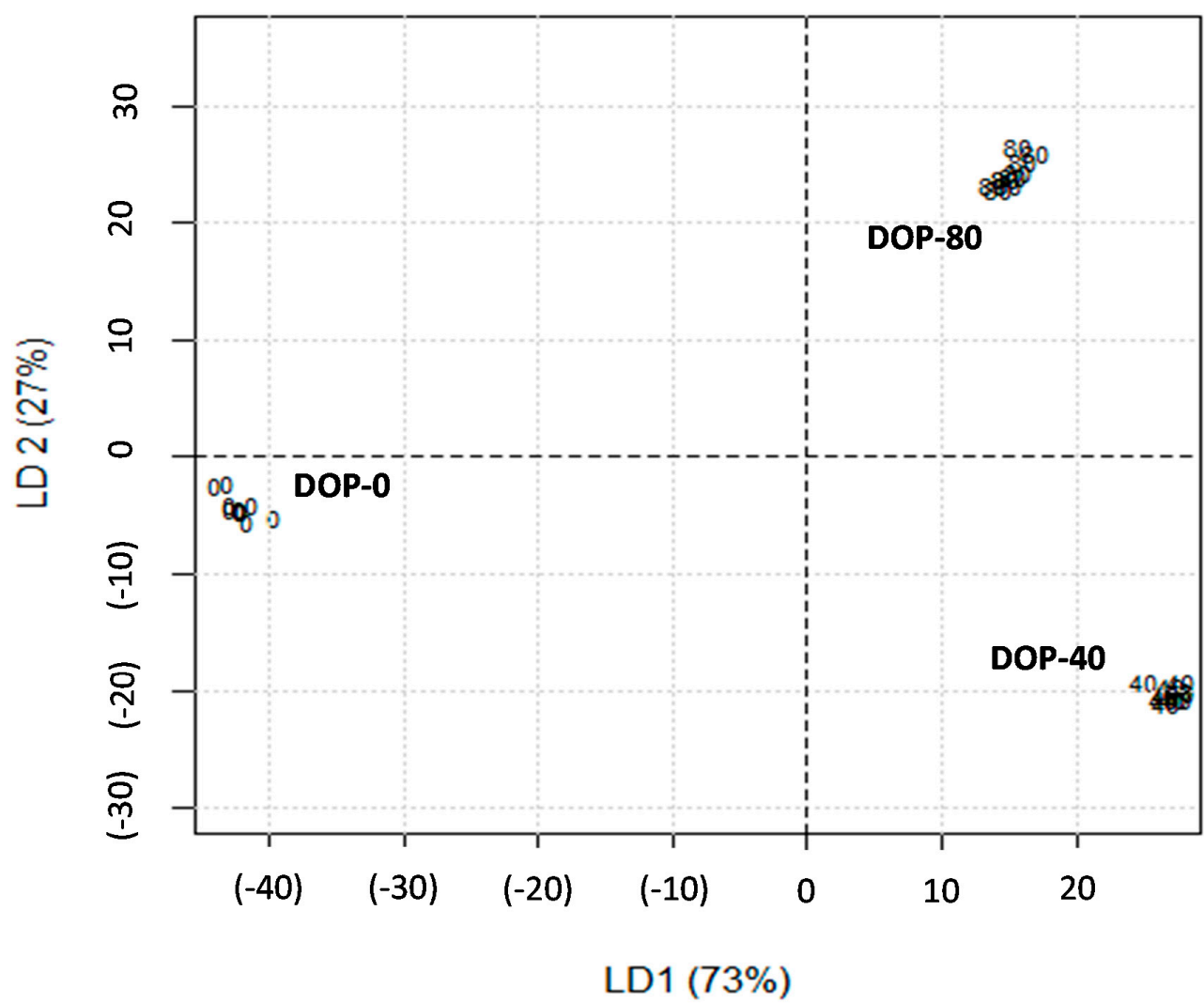

Figure 1. Analysis of observed variables that discriminate the meat of suckling kid goats from three dam diet treatments: commercial concentrates with alfalfa hay (DOP-0), concentrate including $40 \%$ of replacement of cereals by pellets of dehydrated orange pulp and alfalfa hay (DOP-40), and concentrate including $80 \%$ of replacement of cereals by pellets of dehydrated orange pulp and alfalfa hay (DOP-80).

We performed a discriminant analysis to quantify the contribution of each variable to the differences observed among the three treatments. Since the number of variables analysed is very large, only those variables that were significantly different $(p<0.05)$ according to a permutation ANOVA test were selected in the model. The resulting model was used to identify the key variables that contribute to the differences in the meat suckling kid goats based on meat quality parameters, FA profile, and volatile compound content. Function 1 of the discriminant analysis accounted for $72.9 \%$ of the total variation among feeding strategies and it was mainly determined by the absence (DOP-0) or presence of DOP in goat feed (DOP-40 and DOP-80). This function clearly discriminated the effect of including DOP in goat feed, with meat from goats fed using DOP on the right and meat from goats fed with concentrate 
without DOP on the left. The parameters of colour $\mathrm{L}^{*}, \mathrm{a}^{*}$, and hue angle determined the variability assigned to LD1 (Table 3).

On the other hand, Function 2 discriminated three groups (27.0\%) taking into account the level of DOP included in the feed. The high-DOP concentrate group (DOP-80) was in the upper quadrant with the highest aromatic compound content (i.e., ethyl furan, dimethyl disulphide and heptane; Table 5), whereas the groups of concentrates not including DOP (DOP-0) and with low DOP (DOP-40) were in the lower quadrant with the highest monounsaturated FA content (Table 4). The ability of LDF1 and LDF2 to separate the three groups suggests that using DOP in the feeding regime of goats could affect the kids' meat colour, the prevalence of some volatile compounds (ethyl furan, dimethyl disulphide, and heptane), and MUFA content.

\section{Conclusions}

We can recommend replacing from $40 \%$ to $80 \%$ of cereals with dehydrated orange pulp (DOP) in the diet of mother goats, given that it is unlikely that this will cause significant changes in the physical and chemical properties of the kids' meat. Moreover, including DOP in dams' diets improves untrained panellists' appraisal of the sensory characteristics of the kids' meat. This is mainly due to flavour quality, which can be attributed to the increased development of volatile compounds such as ethyl furan, dimethyl disulphide, and heptane observed in kid goat meat obtained from goats fed with DOP. In addition, including DOP in goat diets may improve the nutritional indices of fatty acids in kid goat meat for human health, since it contributes to the reduction of n-6/n-3 and thrombogenicity indices and an increase of the PUFA/SFA index. C18:1 FA and certain volatile compounds (furans, sulphur compounds, and aliphatic hydrocarbons) may be considered to be the main discriminators for kid goat meat obtained by including DOP in goat feed. From the perspective of sustainable development, $\mathrm{DOP}$ is available as an orange industry by-product and represents a plausible strategy for improving the profitability of goat production for farmers.

Author Contributions: Conceptualization: J.L.G., M.D.-P., A.H.; Methodology: J.L.G., M.D.-P., M.J.B., R.P., L.Á.Z., A.H.; Formal analysis: J.L.G., M.D.-P., M.J.B., L.Á.Z., A.H.; Data curation: J.L.G., M.D.-P., R.P., A.H.; Writing-Original draft preparation: J.L.G., M.D.-P., R.P., L.Á.Z., A.H.; Writing—review and editing: J.L.G., M.D.-P., M.J.B., R.P., L.Á.Z., A.H.; Supervision, project administration and funding acquisition: J.L.G., M.D.-P. All authors have read and agreed to the published version of the manuscript.

Funding: This research was supported by a Regional Project funded by Excma. Diputación de Huelva, Spain.

Acknowledgments: The authors are grateful to Excma. Diputación Provincial de Huelva (Spain) for their financial support, Cítricos del Andévalo, S.A. (García Carrión) for supplying pellets of dehydrated orange pulp and OVIPOR, Soc.Coop. The authors wish to thank the farm staff of Huelva University for their technical support and the Servicio General de Investigación Agraria (Universidad de Sevilla, Spain) and the Public University of Navarre (Spain) for their technical assistance in the FA analysis.

Conflicts of Interest: The authors declare no conflict of interest. The funding sponsors had no role in the design of the study, the collection, analysis or interpretation of data, the writing of the manuscript or the decision to publish the results.

\section{References}

1. FAOSTAT. Available online: http://www.fao.org/faostat/es/\#data/QA (accessed on 30 July 2019).

2. Marichal, A.; Castro, N.; Capote, J.; Zamorano, M.J.; Argüello, A. Effects of live weight at slaughter (6, 10, and $25 \mathrm{~kg}$ ) on kid carcass and meat quality. Livest. Prod. Sci. 2003, 83, 247-256. [CrossRef]

3. MAPA. 2019. Available online: https://www.mapa.gob.es/es/agricultura/temas/default.aspx (accessed on 30 July 2019).

4. Bampidis, V.; Robinson, P. Citrus byproducts as ruminant feeds: A review. Anim. Feed Sci. Tech. 2006, 3-4, 175-217. [CrossRef]

5. Inserra, L.; Priolo, A.; Biondi, L.; Lanza, M.; Bognanno, M.; Gravador, R.; Luciano, G. Dietary citrus pulp reduces lipid oxidation in lamb meat. Meat Sci. 2014, 96, 1489-1493. [CrossRef] [PubMed] 
6. Piquer, O.; Ródenas, L.; Casado, C.; Blas, E.; Pascual, J. Whole citrus fruits as an alternative to wheat grain or citrus pulp in sheep diet: Effect on the evolution of ruminal parameters. Small Rumin. Res. 2009, 83, 14-21. [CrossRef]

7. Caparra, P.; Foti, F.; Scerra, M.; Sinatra, M.C.; Scerra, V. Solar-dried citrus pulp as an alternative energy source in lamb diet: Effects on growth and carcass and meat quality. Small Rumin. Res. 2007, 68, 303-311. [CrossRef]

8. Vasta, V.; Nudda, A.; Cannas, A.; Lanza, M.; Priolo, A. Alternative feed resources and their effects on the quality of meat and milk from small ruminants. Review. Anim. Feed Sci. Tech. 2008, 147, 223-246. [CrossRef]

9. AOAC. Association of Official Analytical Chemist. Official Methods of Analysis, 17th ed.; Horwitz, W., Latimer, G., Eds.; AOAC International: Arlington, VA, USA, 2000.

10. Delgado-Pertíñez, M.; Gutiérrez-Peña, R.; Mena, Y.; Fernández-Cabanás, V.M.; Laberye, D. Milk production, fatty acid composition and vitamin E content of Payoya goats according to grazing level in summer on Mediterranean shrublands. Small Rumin. Res. 2013, 114, 167-175. [CrossRef]

11. Nsahlai, I.V.; Goetsch, A.L.; Luo, J.; Johnson, Z.B.; Moore, J.E.; Sahlu, T.; Ferrell, C.L.; Galyean, M.L.; Owens, F.N. Metabolizable energy requirements of lactating goats. Small Rumin. Res. 2004, 53, 253-273. [CrossRef]

12. European Communities. Council Regulation (EC) No 1099/2009 of 24 September 2009 on the protection of animals at the time of killing. Off. J. Eur. Communities 2009, L 303, 1-30.

13. CIE (Comission International de l'Éclairage). Official Recommendations on Uniform Colour Spaces. Colour Difference Equations and Metric Colour Terms; Suppl. No.2; CIE Publication No. 15 Colourimetry; International Commission on Illumination: Paris, France, 1986.

14. Guzmán, J.L.; Vega, F.; Zarazaga, L.A.; Argüello, A.; Delgado-Pertíñez, M. Carcass characteristics and meat quality of Payoya breed conventionally and organically reared dairy goat suckling kids. Ann. Anim. Sci. 2019, 19, 1143-1159. [CrossRef]

15. Hornsey, H.C. The colour of cooked cured pork. I.- Estimation of the Nitric oxide-Haem Pigments. J. Sci. Food. Agric. 1956, 7, 534-540. [CrossRef]

16. Ripoll, G.; Alcalde, M.J.; Horcada, A.; Campo, M.M.; Sañudo, C.; Teixeira, A.; Panea, B. Effect of slaughter weight and breed on instrumental and sensory meat quality of suckling kids. Meat Sci. 2012, 92, 62-70. [CrossRef] [PubMed]

17. Gutiérrez-Peña, R.; Fernández-Cabanás, V.M.; Mena, Y.; Delgado-Pertíñez, M. Fatty acid profile and vitamins $\mathrm{A}$ and $\mathrm{E}$ contents of milk in goat farms under Mediterranean wood pastures as affected by grazing conditions and seasons. J. Food Compos. Anal. 2018, 72, 122-131. [CrossRef]

18. Horcada, A.; Ripoll, G.; Alcalde, M.J.; Sañudo, C.; Teixeira, A.; Panea, B. Fatty acid profile of three adipose depots in seven Spanish breeds of suckling kids. Meat Sci. 2012, 92, 89-96. [CrossRef] [PubMed]

19. Ulbricht, T.L.V.; Southgate, D.A.T. Coronary heart disease: Seven dietary factors. Lancet 1991, 338, 49-56. [CrossRef]

20. AMSA. Research Guidelines for Cookery, Sensory Evaluation And Instrumental Tenderness Measurements of Fresh Meat; American Meat Science Association: Savoy, IL, USA; National Live Stock and Meat Broad: Chicago, IL, USA, 1995.

21. Insausti, K.; Goñi, V.; Petri, C.; Gorraiz, C.; Beriain, M.J. Effect of weight at slaughter on the volatile compound of cooked beef from Spanish cattle breeds. Meat Sci. 2005, 70, 83-90. [CrossRef] [PubMed]

22. Bianchi, F.; Cantoni, C.; Careri, M.; Chiesa, L.; Musci, M.; Pinna, A. Characterization of the aromatic profile for the authentication and differentiation of typical Italian dry-sausages. Talanta 2007, 72, 1552-1563. [CrossRef]

23. Van Den Dool, H.; Kratz, P.D. A generalization of the retention index system including linear temperature programmed gas-liquid partition chromatography. J. Chromatogr. A 1963, 11, S0021-S9673. [CrossRef]

24. Martínez-Cerezo, S.; Sañudo, C.; Medel, I.; Olleta, J.L. Breed, slaughter weight and ageing time effects on sensory characteristics of lamb. Meat Sci. 2005, 69, 571-578. [CrossRef]

25. Oksanen, J.; Blanchet, F.; Friendly, M.; Kindt, R.; Legendr, P.; McGlinn, D.; Minchin, P.; O'Hara, R.; Simpson, G.; Solymos, P.; et al. Community Ecology Package; R Package Version 2.5-4. Available online: https://cran.r-project.org/web/packages/vegan/vegan.pdf (accessed on 17 June 2019).

26. Rencher, A.C. Methods of Multivariate Analysis, 2nd ed.; John Wiley and Sons INC: Hoboken, NJ, USA, 2002.

27. Venables, W.; Ripley, B. Modern Applied Statistics, 4th ed.; Springer: New York, NY, USA, 2002; p. 498.

28. Chilliard, Y.; Ferlay, A.; Rouel, J.; Lamberet, G. A review and nutritional and physiological factors affecting goat milk lipids synthesis and lipolysis. J. Dairy Sci. 2003, 86, 1751-1770. [CrossRef]

29. Argüello, A.; Castro, N.; Capote, J.; Solomon, M. Effects of diet and live weight at slaughter on kid meat quality. Meat Sci. 2005, 70, 173-179. [CrossRef] [PubMed] 
30. Webb, E.C.; Casey, N.H.; Simela, L. Goat meat quality. Small Rumin. Res. 2005, 60, 153-166. [CrossRef]

31. De la Vega, F.; Guzmán, J.L.; Delgado-Pertínez, M.; Zarazaga, L.A.; Arguello, A. Fatty acid composition of muscle and internal fat depots of organic and conventional Payoya goat kids. Span. J. Agric. Res. 2013, 11, 759-769. [CrossRef]

32. Wang, Y.; Jacome-Sosa, M.; Proctor, S. The role of ruminant trans fat as a potential nutraceutical in the prevention of cardiovascular disease. Food Res. Int. 2012, 46, 460-468. [CrossRef]

33. Campo, M.M.; Nute, G.R.; Hughes, S.I.; Enser, M.; Wood, J.D.; Richardson, R.I. Flavour perception of oxidation in beef. Meat Sci. 2006, 72, 303-311. [CrossRef]

34. Partida, J.A.; Olleta, J.L.; Sañudo, C.; Albertí, P.; Campo, M.M. Fatty acid composition and sensory traits of beef fed palm oil supplements. Meat Sci. 2007, 76, 444-454. [CrossRef]

35. Wood, J.D.; Richardson, R.I.; Nute, G.R.; Fisher, A.V.; Campo, M.M.; Kasapidou, E.; Sheard, P.R.; Enser, M. Effects of fatty acids on meat quality: A review. Meat Sci. 2004, 66, 21-32. [CrossRef]

36. Van Ba, H.; Hwang, I.; Jeong, D.; Touseef, A. Principle of meat aroma flavors and future prospect. In Latest Research into Quality Control; Akyar, I., Ed.; Intech Open Science: Rijeka, Croatia, 2012; pp. 145-176.

37. Vasta, V.; Ratel, J.; Engel, E. Mass spectometry analysis of volatile compounds in raw meat for the authentication of the feeding background of farm animals. J. Agr. Food Chem. 2007, 55, 4630-4639. [CrossRef]

38. Kondjoyan, N.; Berdagué, J.L. A Compilation of Relative Retention Indices for the Analysis of Aromatic Compounds; Laboratoire Flaveur, INRA-Theix: Clermont Ferrand, France, 1996; p. 234.

39. Rychlik, M.; Schieberle, P.; Grosch, W. Compilation of Odor Thresholds, Odor Qualities and Retention Indices of Key Food Odorants; Deutsche Forschungsanstat für Lebensmittelchemie and Instit für Lebensmittelchemie der Technischen Universitat München: Munich/Freising, Germany, 1998; p. 63.

40. Roldán, M.; Ruiz, J.; Pulgar, J.S.; Pérez-Palacios, T.; Antequera, T. Volatile compound profile of sous-vide cooked lamb loins at different temperature-time combinations. Meat Sci. 2015, 100, 52-57. [CrossRef]

41. Limacher, A.; Kerler, J.; Davidek, T.; Schmalzried, F.; Blank, I. Formation of furan and methylfuran by maillard-type reactions in model systems and food. J. Agr. Food Chem. 2008, 56, 3639-3647. [CrossRef]

42. FEDNA. Composición y Valor Nutritivo De Alimentos Para La Fabricación De Piensos Compuestos, 3rd ed.; Fundación Española para el Desarrollo de la Nutrición Animal: Madrid, Spain, 2016; p. 502. Available online: http://www.fundacionfedna.org/ingredientes-para-piensos. (accessed on 12 March 2019).

43. Bravo-Lamas, L.; Barron, L.; Farmer, L.; Aldai, N. Fatty acid composition of intramuscular fat and odour-active compounds of lamb commercialized in northern Spain. Meat Sci. 2018, 139, 231-238. [CrossRef] [PubMed]

44. Farmer, L.; Hagan, T.; Paraskevas, O. Role of selected precursors in meat flavor formation. In Quality Attributes of Muscle Foods; Xiong, Y.L., Ho, C.T., Shahidi, F., Eds.; Springer: New York, NY, USA, 1999; pp. 159-172.

45. Madruga, M.; Elmore, J.; Dodson, A.; Mottram, D. Volatile flavour profile of goat meat extracted by three widely used techniques. Food Chem. 2009, 115, 1081-1087. [CrossRef]

46. Mottram, D. Flavour formation in meat and meat products: A review. Food Chem. 1998, 62, 415-424. [CrossRef]

47. Rochat, S.; Chaintreau, A. Carbonyl odorants contributing to the in-oven roast beef top note. J. Agr. Food Chem. 2005, 53, 9578-9585. [CrossRef]

48. Elmore, S.; Cooper, S.; Enser, M.; Mottram, D.; Sinclair, L.; Wilkinson, R.; Wood, J. Dietary manipulation of fatty acid composition in lamb meat and its effect on the volatile aroma compounds of grilled lamb. Meat Sci. 2005, 69, 233-242. [CrossRef]

49. Resconi, V.; Campo, M.M.; Montossi, F.; Ferreira, V.; Sañudo, C.; Escudero, A. Relationship between odour-active compounds and flavour perception in meat from lambs fed different diets. Meat Sci. 2010, 85, 700-706. [CrossRef]

(C) 2020 by the authors. Licensee MDPI, Basel, Switzerland. This article is an open access article distributed under the terms and conditions of the Creative Commons Attribution (CC BY) license (http://creativecommons.org/licenses/by/4.0/). 